\title{
蘇聯語言舁走上了新的道路
}

\section{維諾格勒多夫著 余元盒譯}

\section{第 一 站}

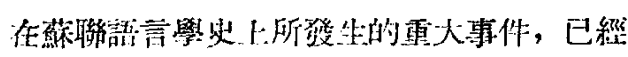

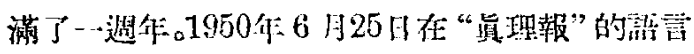

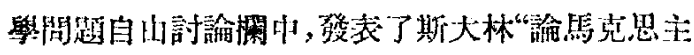

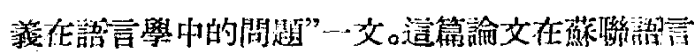

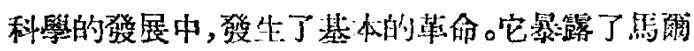
院士理論底非溤克思主義的、非科學的本質、它對

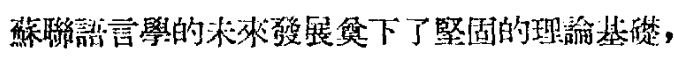

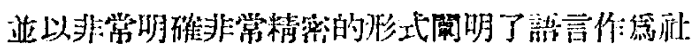
會現貌的本質，墽明了它的特徽，它的社會機能， 棈造, 它與思維的關係, 它的基本規律以及它的养 展迹徑。

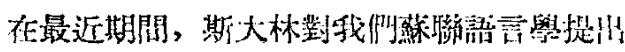
了三大任䂆：第一——消隇卧爾的叮徒和其繼承

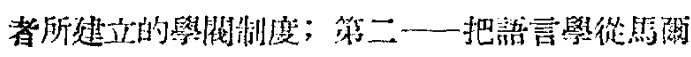

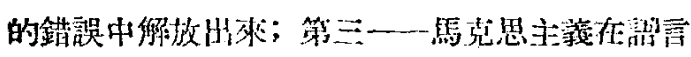
學中的筫施。這湖最後的任務一一是主要的任務, 而首二個任務一一是對它的創选性僻决和完成船 故的必留前提和必留俆作。

把馬克思主義實施在語言學中 便是在

馬 - 列主義經典著作中所提供的, 特别是斯大林

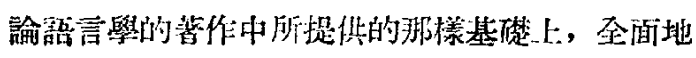

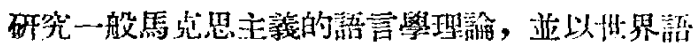

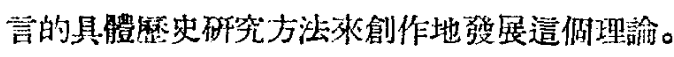

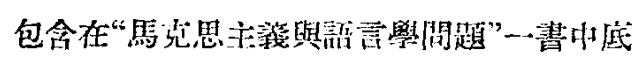
斯大林論語言學著作，對語言學慰示了光明的遠 景, 並以創造的馬克思主義底新思想和新䋹諭蘴 曾了一切思想戰綫的工作人員，一切社會科學 家。

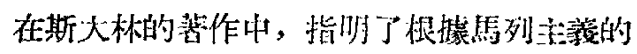

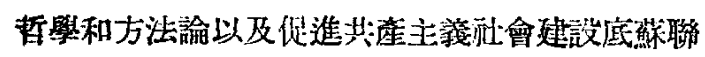
科學進一步發展的任務。斯大林十分榡斷地强調

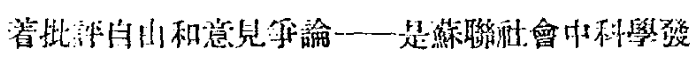

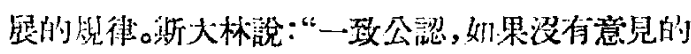

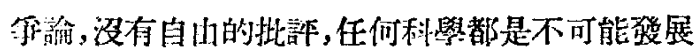
的, 不可能進步的”。創你的討論, 應該慗助着克服 矛盾, 應該幫助着統一的堅决的解决乎論的科學

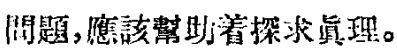

思想家的偉大著作這樣迅速面順利地把語言

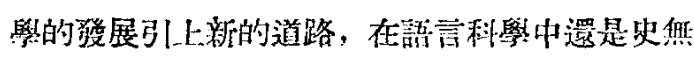

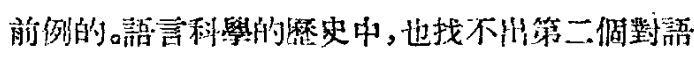
言學思想的進展表現了這樣上大而健康的影響的 莘作。

在蘇聯泟會中, 科學有機地與賽際結合起來。

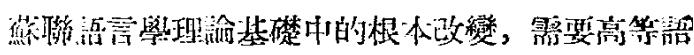

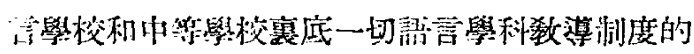
改革。

在相當短的時期內，編成了高學學校中浯言 學基朴理涂教程的新提網。特别注意到語言史教 程的正確組織。

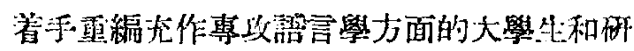
笲生朋底科學研究工作泛設計(還米完成)；伀招 斯大林的英师指示提出了新的閣題。基本詞築，詞

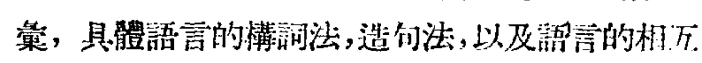
留係和文體問題的研究, 佔了重要的地位。

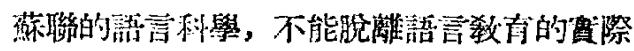
而發是，特别是在我椚多民族國家之中。

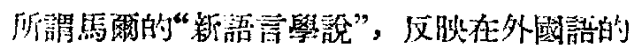
教授法上, 可能是非甞有害的影響。關於瑪爾理論 中語滈和思維的關係問題之不正確解决, 引道到 教育過程中本國語和外國語的互相作用問題论不

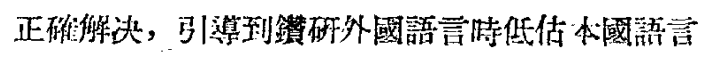

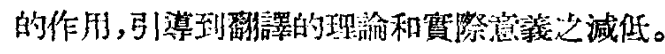

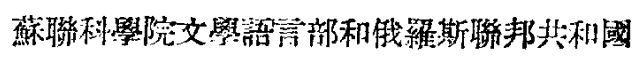

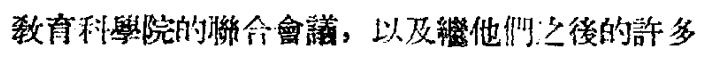




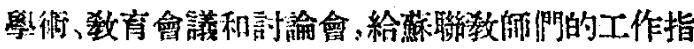
出了正碓的科學道路。

值得注意，目於斯大湘的著作，浯言學問題已

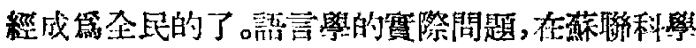
工作者間,遭受了廣泛的創作性尌論。

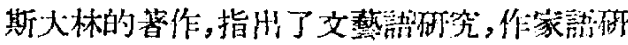

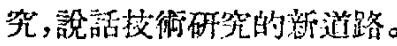

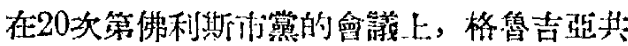
産黨(布)中央委員會書記祭爾克維:安 (T. Чарквиан)

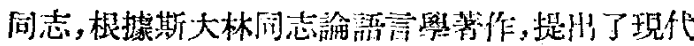
格鲁吉亞的文學浯言問面。他說及必須從它的擬

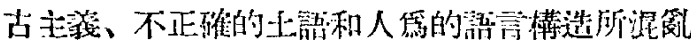

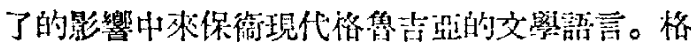
鲁吉亞的知識分了，被號召起來第了等取格鲁吉

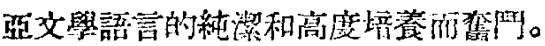

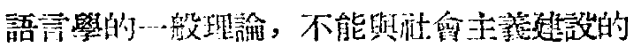

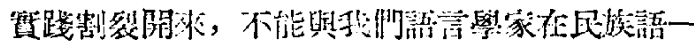

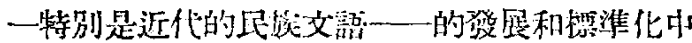

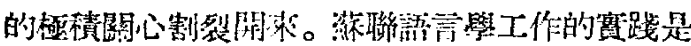
與列禁斯大林的民质政策不可分割的。它以斯大

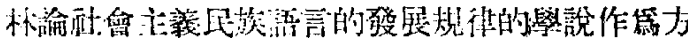
[i门?

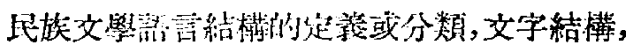

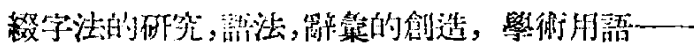

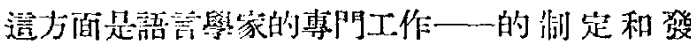

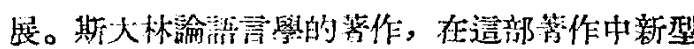

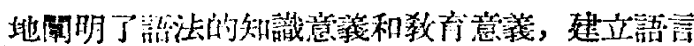

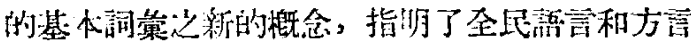

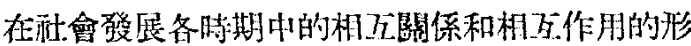

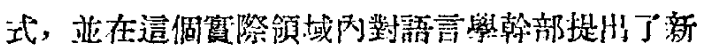
的任弱。

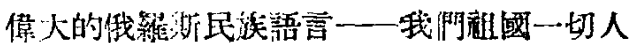
且的最有力交際工具。千千萬萬冬尼族的人們都 用俄語思策和說話, 如用他們极族語言一棈。偉大

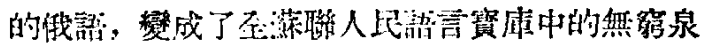
源。

\section{茅二 節}

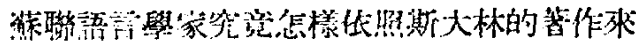

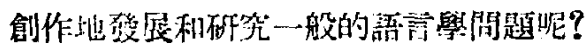

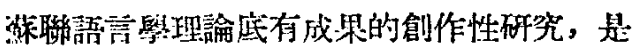

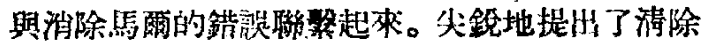

語言學基居的任務, 在語言學的理論和䨘際中根

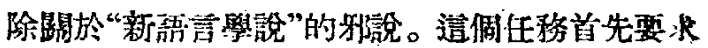

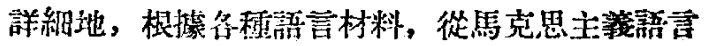

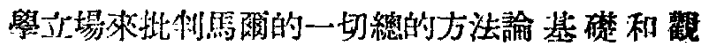
啙。斯大林间志, 把䭴爾關於語棓“階級性”的公

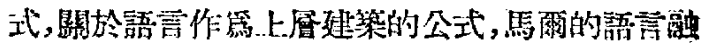
命的理諭，馬网的語言和思維墢屡中的階段性的 理渝, 以自己的分析作了如此批評的天才典型。

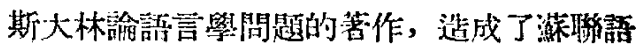

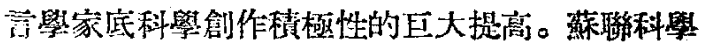
院浯霄學研究所付印了以“反對馬克思主義在語。

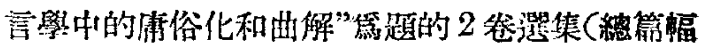
計 80 张印刷綪型)。在譈部選集中，把馬爾院士，

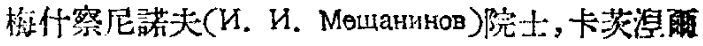
松 (С. Д. Кацнельсон) 呚授, 雅可符列夫(H. $\Phi$. Яковлев)教授, 菲林(Ф. П. Филин)教授, 以及“新 部吾學說”的其:他代表者之訢多著作，從斯大林論 部吾學說的原理中，加以分析和研究。與暴路馬爾 和期門徒的錯㟝䠰係－上，在這部選集中發展了斯 大林論語言學說的基本原则和基本原理。

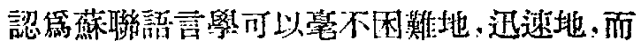
且一筞永逸地完服馬爾的鉷誤，那是過分樂觀的 表現。對於這點，必須雔力與語言學幹部進行思 想、政治的和科學敎行的工作。

廣泛而全䤄地發昆一下斯大林问志的著作在 與他們的各種語言璂碟研觉上所絬合起來的創作 性實施工作。這项工作的首要成果, 是二部選集：

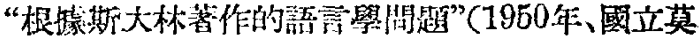
斯科大學出版部)和“現代俄䈃的造句法問题”(國 立教育出版局, 1950年云), 它已在出版物_上得到了

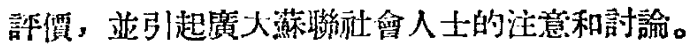
在灌聯科學院文學語言部會議上, 在烏克阑科學 院和其:他各扠盟热和國科學院會議上，都發表了 許多報告和演說。

科學院哣言學研究所所作成的理諭性交章選 集, 是最深刻和最完備的具體資料(“灌聯語言學

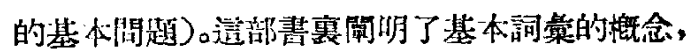
確定了它既適合於㑬别的文適合於十分多種多椂

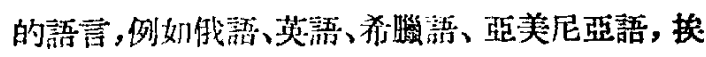

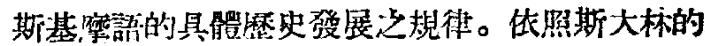
語法定義和它的內容來研究例如俄語中的锚、時、 讷那椂的語法分類的發展; 對各系語言材料、研究

第细期 


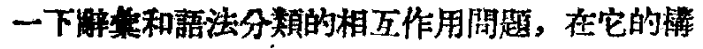
詞法和造句法方面、分析一下語法構造和相五關 保。在有些文音中，阙朋了語普學與試圆確定語 音學在其他語霄學科中的地位有關的一般開题。

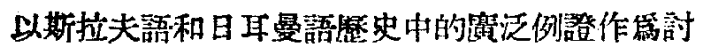

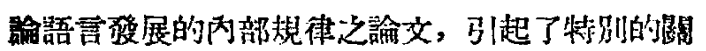
心。

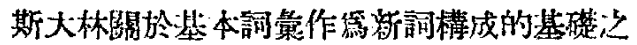
學說、提出了閶於部詞的構造阔题，提出了關於它

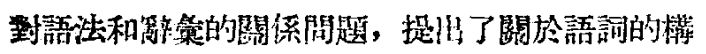

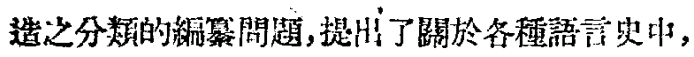

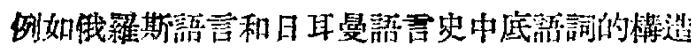

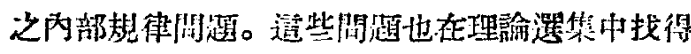
了反肤。在這部書赛也刊登了若汗著作，造些著作

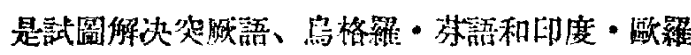

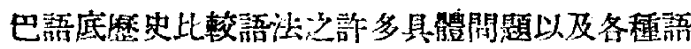

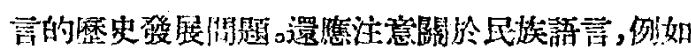
挷威語的構造之研究，以及關於語言的分期和陮 合過程之研究。

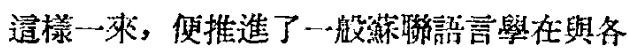

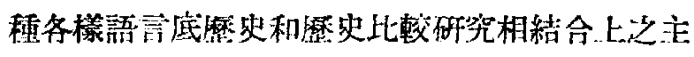
要原理的創立和發展的工作。

邆項工作是篹中在部言理渝的如下主要內容 上:

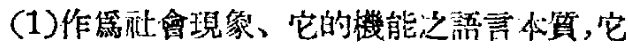

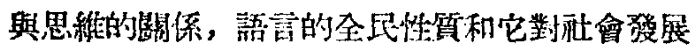
底意㼁。

(2)語言的結模,它的特徽; 不變的 “語言基

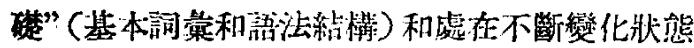
中之語言底詞郠。

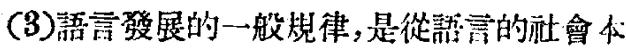
算和它的結構出發的(新的品質要素、新的結構品

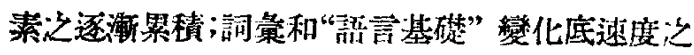
不均衡性,部言的內部改進和其他等等)。

(4)全民語言和從那些語富—— 民族方言和 各階級同行䎸一一襄發生的“支派”,與社會史、民

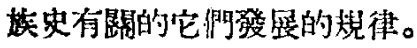

(5)民族語和文學語言在社會史各階段，上的 聯繁, 相正作用和相五關係。

（6）文㙯語，在企民語鼠任上的作家語; 在作 家語中作家風格和作品體裁的倜別和全民的概 念; 文體和宇留觀。

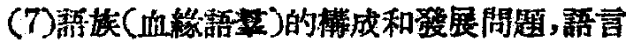
親族關係的倠定方法、語言學和人種考古學，它們 在解决和嗾和語言的起源上之相互作用，世界浯

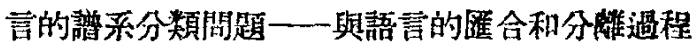
中的一般問題度關。

（8）民族語的櫂史發展問題一一從氏族語 部落語, 從部落語到部族語和民族等。

對研究斯大林著作中所阔明的民族畺形成的 過程, 予以特別注意。首先給椎爾斯克 - 奥勒爾

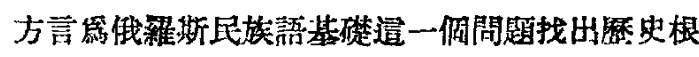
據。

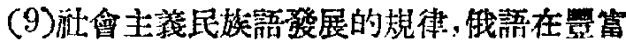
蘇聯各民族浯成泀策過程中的作用。

(10)帮言學的軎門方法，歴史比較法和它的

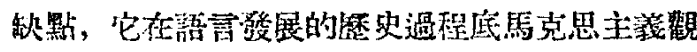

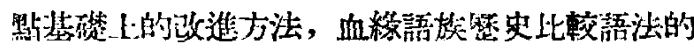
建立原则。

(11)玹照斯大林論語言學說的語言學結構:

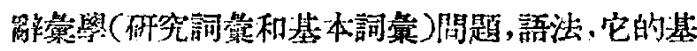

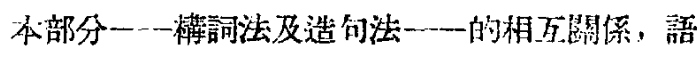
義祭和它在語言學系統中的地位, 語竟學在涪多 其他浯言科學中的地位, 話詞的榡造對於其他語 言學科的㬎係。

今年的語言學研究大部分，是釗對各種語言、

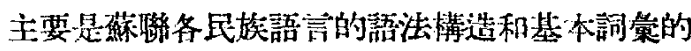
硼究方涌。文化建設和人民教育的惯際需要, 各種

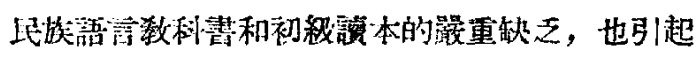

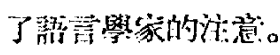

被激發起來的語富學思想的創造工作，正引 起冬方面的注意。

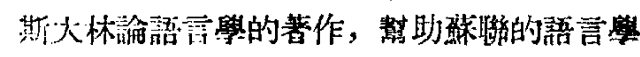

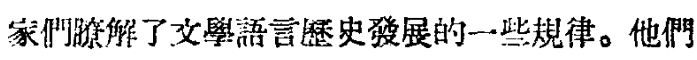

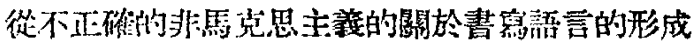
過程和進化過程的階放基礎的觀念中，把它們(指 程史發展规律)解放出來。他們給文學語言的新的

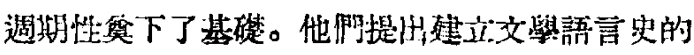
新原則。

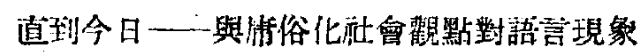

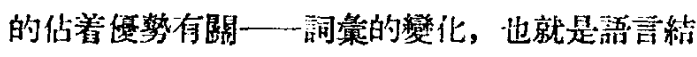
構底更活動的和更不固著的因素，通常都放在文 學語言發展特徵的基礎上。斯大林教導伐們說，從

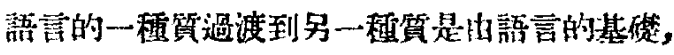




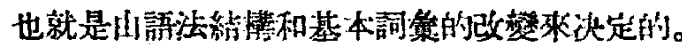

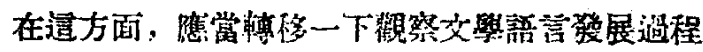

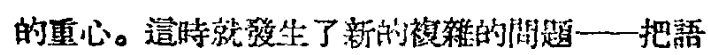
言詞登發展底基本階段與語言結棈及其由一種質 過渡到另一種定底溷渐發展的梘律聯繁起來。

，斯大林的著作，势趿我們绩碓地筧定了文學 語言和大笔語在社會發展的各洔期中的關倸。文

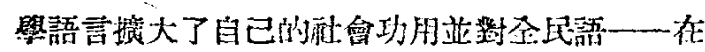
民族形成的複雜過程中一一發生了最密切的距

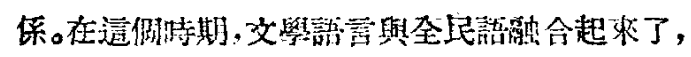

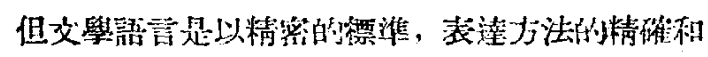

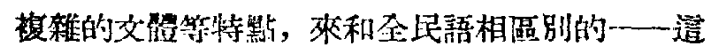
是它內部的體系。

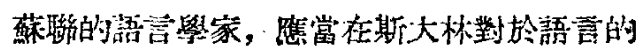

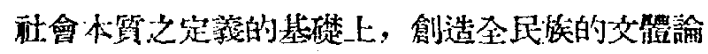

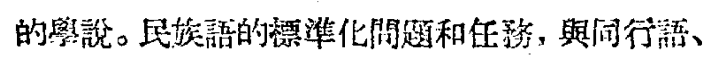

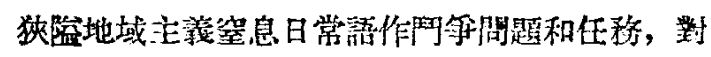

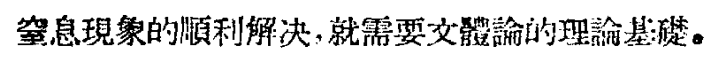
民族語的文體諭，應賞皘極地促進文化語的長成。

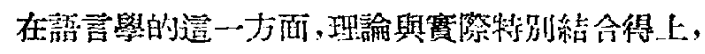
理諭與䁈際有內在的聯繁。作家應嫦對於全是語

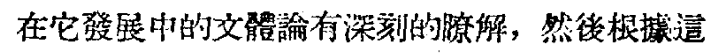
程臆解來察作。

斯大杪的語法定㼁,正如人類思維底曼期的、

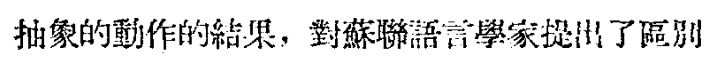

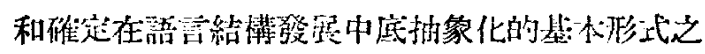

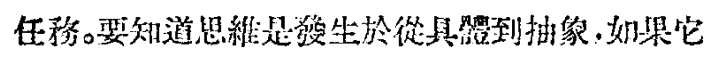

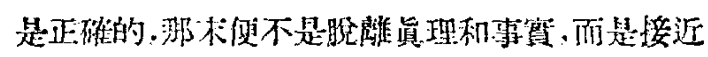

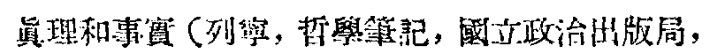
1947年, 146项)。

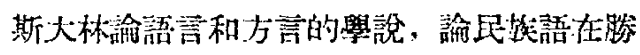
利的方言基礎上形成起來的學說, 使我们能够重

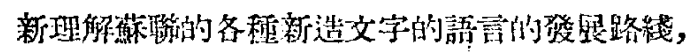

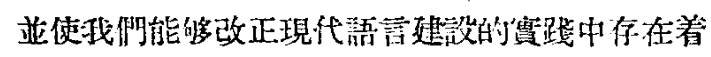

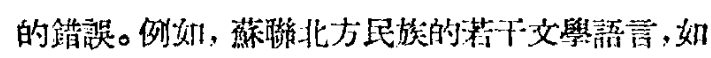

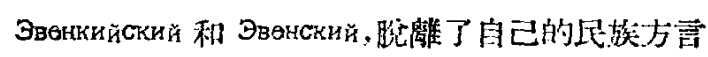

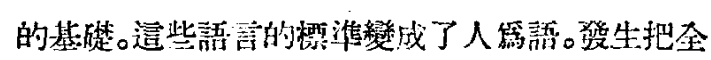

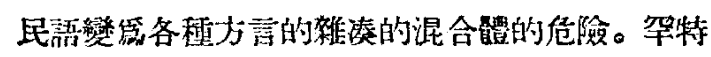

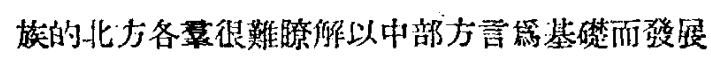
起來的罕特文學語言, 說中部方言的人通常摆都 精通俄語並且很少借助於自己的交學化了的語 言。

\section{第四期}

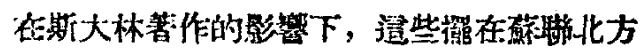
民族部富研究人貝面前的閣題, 就是第了改正現

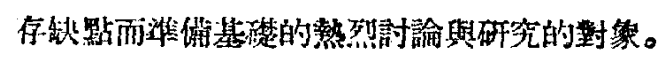

斯大标的著作，引起了全部蟙大的、包括 15 種 左存語言的鳥格里 - 芬語言學著作的根本修改,

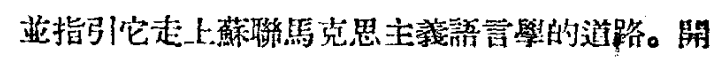

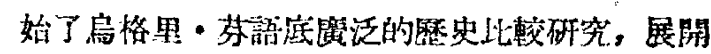

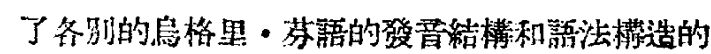
研究工作。

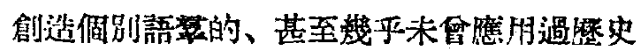
比较研究法的那些語量的比較浯法工工作, 正在開 始展開。例如，用在斯大林著作活現以後，便㢄泛 地認識到以整史比較法研究達格斯坦 (Дагестан)

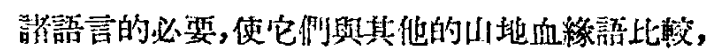

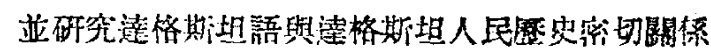
下的發昆少向。

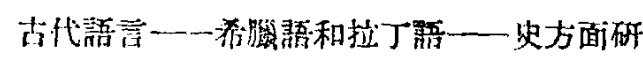

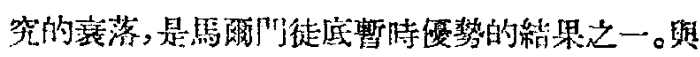

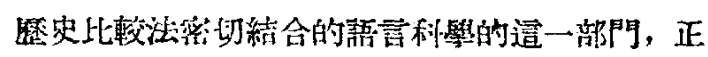
在润始惔復。

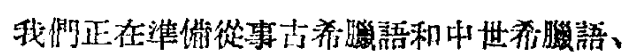

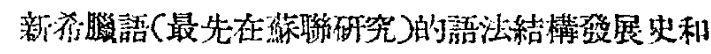

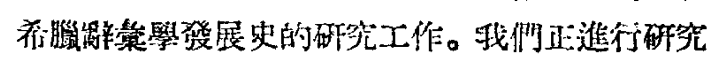

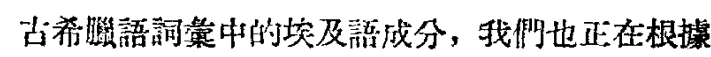
馬克思主戔對於語言融合的社會規律的觀點來完 成拉厂語史的研究——提仙拉丁語暦史發展的新 概念; 對拉丁势發展的內部規律予以極大的注意。

斯大林的著作，帮助我們對於蘇聯各尼族語 探用俄語裹的國際衔語和俄語的社會政浩的詞喼

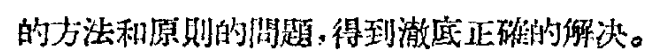

文化語和新造文字的語言的縓造的望政 問

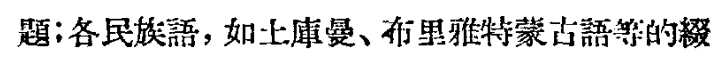

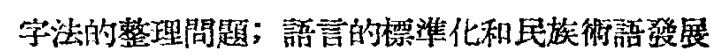
的問題; 翻譯問题等, 在許多民矮共和闻和各省中 都是很尖銃很複新的。他們要求中央的語言舆研 究機構方面，例如，蘇聯利學院語言研究所方面的 皘極注意和惯際赫助。抱撴得很,語言學研究所對 這方面的研究，顥然不的主動。由所謂“激語言學

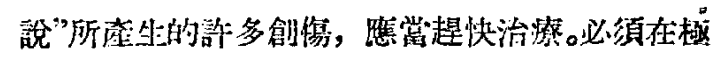

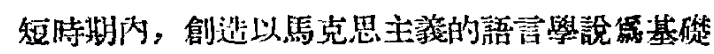
的蘇眑各民族一切語言的語法。

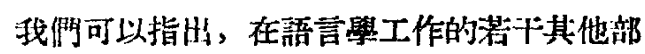


队1]，還可以香得出在完成現代的任務.上，有顆著 的,有時芸至是極易學察的落後性。

蘇聯語言學在“新棓言學說”佔優勢時期—— 根據馬桃及其門徒的要求一一當然放集遺產和祖

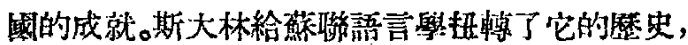
他布责了過去語言科學中底空洞而棗率的否定。

订是這一年來，叙连程國語言學史的批詐著

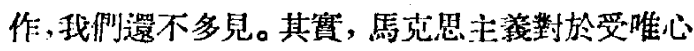
論限湖的科學語言學㯖統，在培多方面不能完成

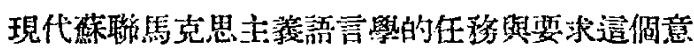
義的闆明，可能使找們的一些語言學家對於部多

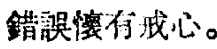

有關語言與思維閣題的馬克思主義研究, 是 語言學管工作的重要部分。關於語言和，思維相互

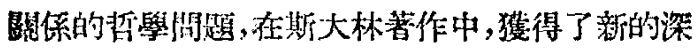

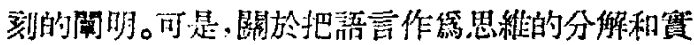

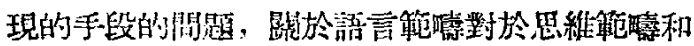

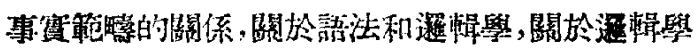

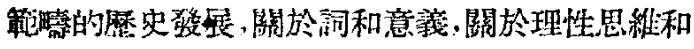

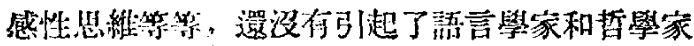
的足够注意，邆沒行在去年和今年獲得智著墢屡。

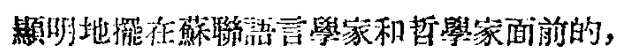

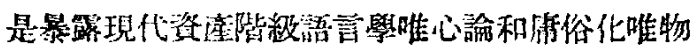
論底反糜生規律的任務。

語言學問題, 如像是在活會性不景策現象中 的本質, 在現代資㐎階級哲學和選輯學的唯心諭

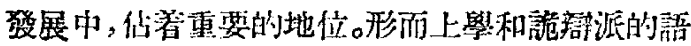
言“猳定性:”的觀念，就表現出逜些在美國特别找 到温床的資彥階級哲學和遂輯學的唯心諭照想的

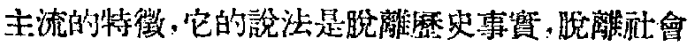

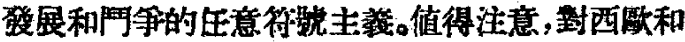

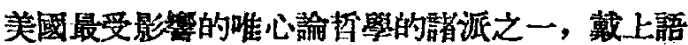

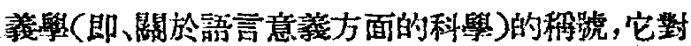

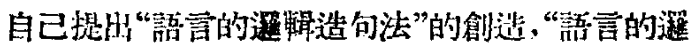
軿分析”的研究等等造樣的任務。維也也緉學派現代

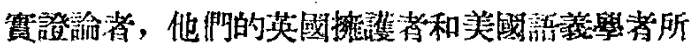
展開的語言的批神, 以及語言的形式化和數學化, 是唯心綝的極端現象之一。

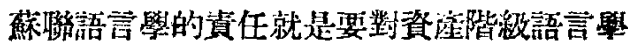
思潮施以溃隇性的批訐。

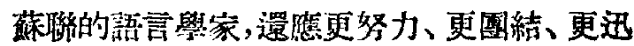
速、更澈底建設蘚証語言學的大厦，這倜大厦的基

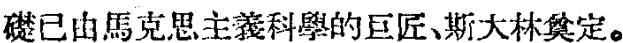

應用馬克思主義在請言學上的任務, 使我們 全體有義務深到掌握創造性的馬克思主䉝, 有義

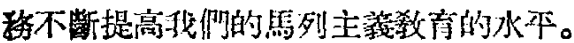

斯大林同志的天才著作 “䮓完䍐主義與語言 閣題”, 證明了不斷發展不断改進的经克思主義底

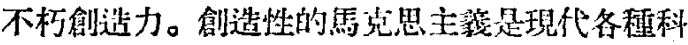

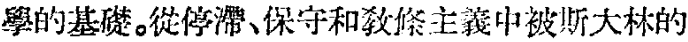

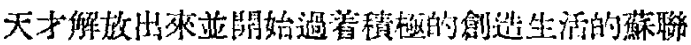
語言學, 應在最近幾年內荙到較重要的成就。

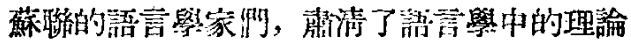

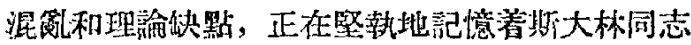
對他們、對他們的刢造性的科學研究工作所說底

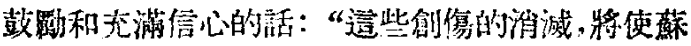

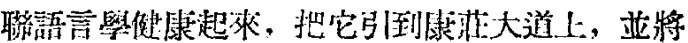

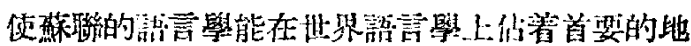
位”。

〔譯自“真理報”,1951年6月20日]

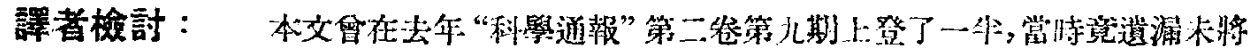

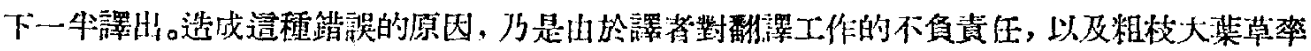

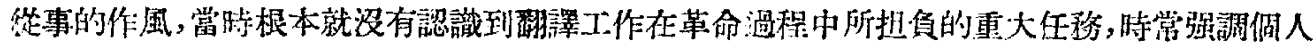

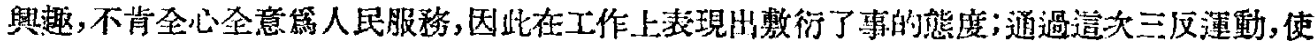

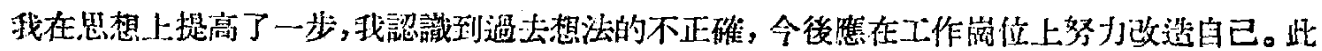

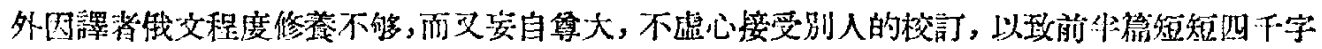

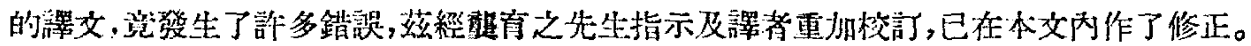

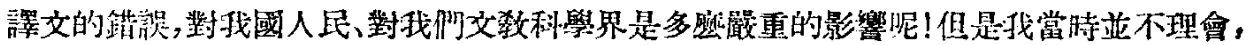

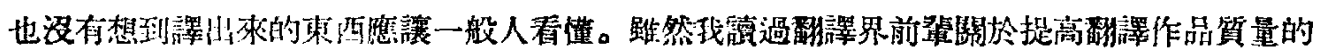
言論, 而我呢却汥有把翻譯工作搞好, 這點重論如何是不能寬恕我自己的。今後找當保登根除

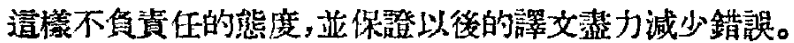

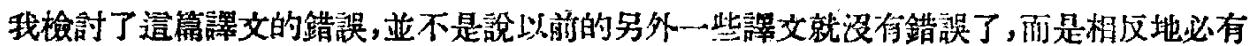




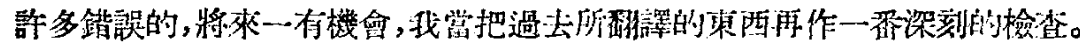

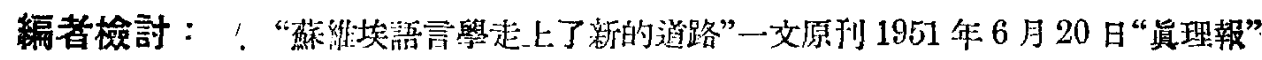

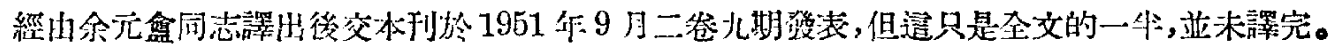

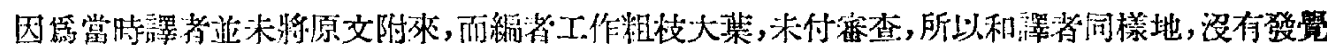

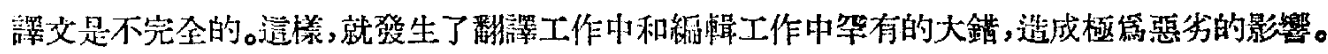

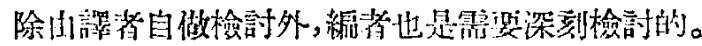

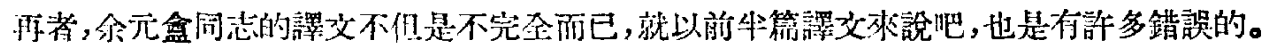

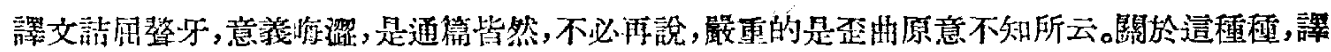

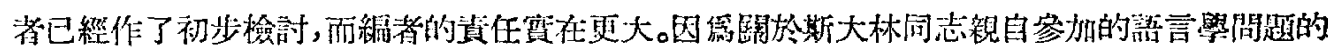

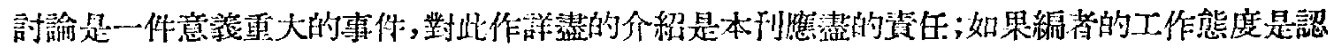

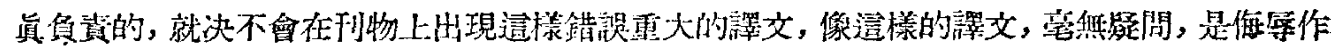

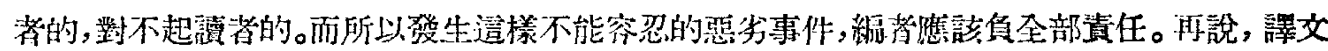

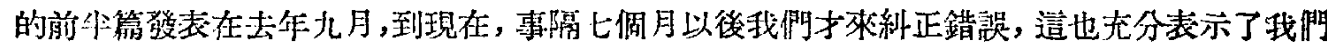
在編蛙工作當中的穊木不仁。

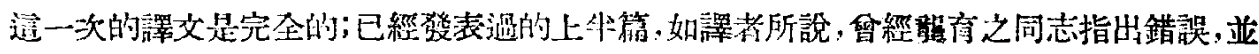

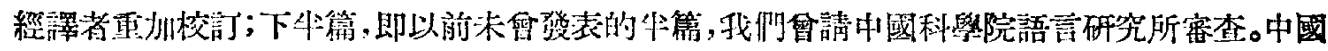

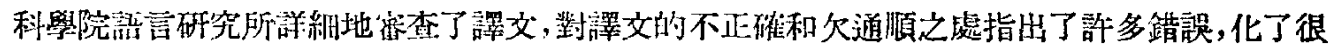
多很多功头。

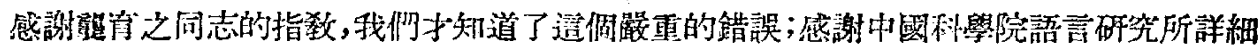

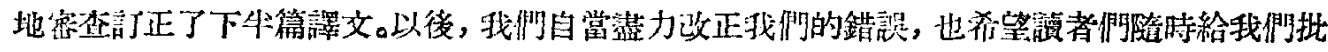
詐。

\section{蘇聯部長會議頒發一九五一年 科學方面斯大林獎金}

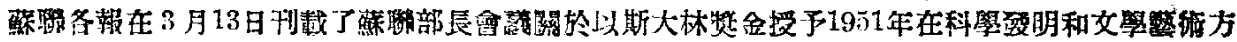

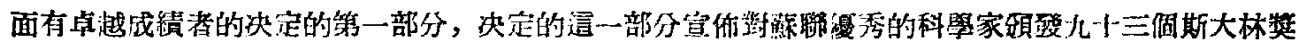

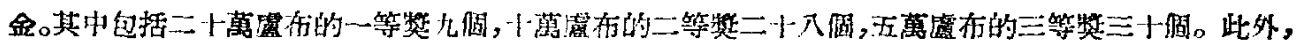

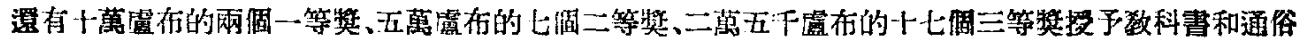
科學著作的䬕著者。

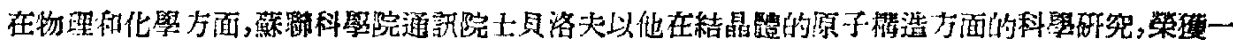

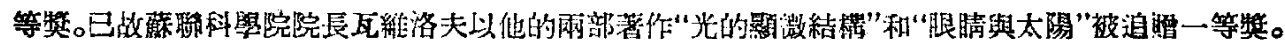
化學家普列感布拉二斯基教授和車爾尼雅耶夫院士也獲得了一等繁。

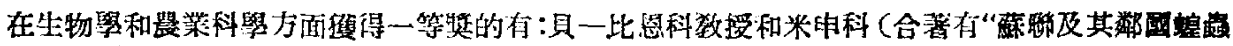

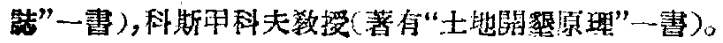

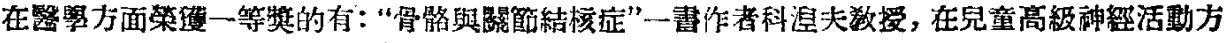

面研究成續卓著的克拉斯諾哥爾斯基敎授。

阿夫迪耶夫致授以他的著倠“東方古代交”復得一等獎。

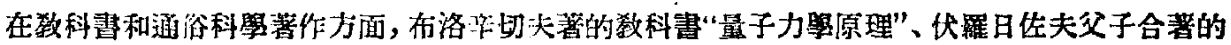

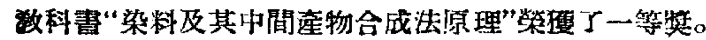

此外，少有大批的物理學家、水力工程學家、化學家、地管學家、生物學家、醫學工作者、歷史學家 等，因卓越的研究和專門的著作，獲得了二等獎和三等獎。

（新華社新聞檑3月15日） 